\title{
Development of Geography Text Books Used by Senior High School Teachers Case Study at East Java-Indonesia
}

\author{
Edy Purwanto ${ }^{1}$, Ach. Fatchan ${ }^{1}$ Purwanto $^{1} \&$ Hadi Soekamto ${ }^{1}$ \\ ${ }^{1}$ Department of Geography, Social Science Faculty, Universitas Negeri Malang (State University of Malang), \\ Malang, Indonesia \\ Correspondence: Hadi Soekamto, Department of Geography, Social Science Faculty, Universitas Negeri Malang \\ (State University of Malang), Malang, Indonesia. Tel: 62-811-373-264. E-mail: Hadi.Soekamto.fis@um.ac.id
}

Received: July 31, 2015

Accepted: November 5, 2015 Online Published: December 15, 2015

doi:10.5539/jel.v5n1p60

URL: http://dx.doi.org/10.5539/jel.v5n1p60

\begin{abstract}
The aim of this study was to analyze the geography text book for: (1) identify and describe the errors in the organization of geography textbooks, and (2) identify and describe the content of the textbook standard errors of geography. The text book is currently being used by teachers of Senior High School in East Java. To analyze the contents of the textbook errors using indicators blend of organizing textbook of Beck and McKeown and content standard textbooks of National Education Standards Agency of the Republic of Indonesia. Data collected by survey techniques against various geography text books used by teachers in Malang, East Java Province. The results showed that the errors found in the textbook Geography: first, errors in organizing textbook includes: (1) aside that overwhelm the purpose amounted of $28.69 \%$, (2) inagequate examples and comparisons amounted of $30.65 \%$, (3) poorly odered components of an explanation of $22.85 \%$ and, (4) inadequate explanation of 17:35\%. Second, the standard error of the contents of the textbook includes: (1) exposure draft of $54.80 \%$, (2) exposure of the facts of $57.10 \%$, (3) exposure generalization of $28.60 \%$, (4) the use of language of $21.40 \%$, and (5) the effective functioning media amounted of $59.50 \%$. Found media functionality in geography text book shows the worst, which is equal of 59.50. It would be bad for the implementation of the national curriculum in 2013 that is currently being used by teachers. Describing the content of bad geography textbooks in the exposure draft (error of $54.80 \%$ ) and the fact (error of $57.10 \%$ ) will result in a weak student mastery of concepts and facts in learning geography material at the Senior High School.
\end{abstract}

Keywords: geography textbook, geography teacher, and Senior High School

\section{Introduction}

Dependence on textbooks teachers in Indonesia in the learning process is still high. Most geography teacher at Senior High School tends to rely on textbooks in teaching. During this time the geography teacher considers learning to use textbooks as the most practical and rapid spending targets subject matter. It was done the geography teacher, because the curriculum prevailing in Indonesia requires the subject matter must be finished on time in every semester. Thus, teachers tend to act practically by way of learning in order of existing textbooks. That fact has been proven by some of the results of previous research, including research results Zevin (1992) that the use of textbooks is an integral part for learning. Research Van Cleaf (1991) found that the dependence of teachers and students in the textbook are: (1) textbook presents information organized well, (2) its use ensures that a particular topic will be taught, and (3) the teachers are busy, often learning to follow the sequence of text books for granted.

In East Java, especially in Malang, mostly teachers, students, and school are very dependent on textbooks in organizing learning. In the case, found most of the textbooks used were not designed with good grip. In fact, the textbooks in Indonesia that publication by the National Education Agency project may be judged as not good. As noted Tempo (2000) that the quality of text books for learning in school quality content is very low. Low quality textbooks, among others, pointed out that there are many misconceptions and facts or data that is difficult to understand the student. Some errors that often occur in the content and organization of text books in the Senior High School as the following description.

One form of error "data content" in a geography textbook Senior High School is shown as follows: "air in Indonesia generally comfortable being in the tropics surrounded by sea. The air temperature is not too hot and not too cold. Temperatures in the lowlands $(0-700$ meters $)$ between $28^{\circ} \mathrm{C}-22^{\circ} \mathrm{C}$. Temperatures in the altitude 
(700-1500 meters) between $22^{\circ} \mathrm{C}-17^{\circ} \mathrm{C}$. In mountainous areas ( 1500 to 2500 meters) the air temperature is between $17^{\circ} \mathrm{C}-11^{\circ} \mathrm{C}$. Temperatures as above generally very pleasant man". Misunderstanding the text content is indicated for sorting temperature of $28^{\circ} \mathrm{C}-22^{\circ} \mathrm{C}, 22^{\circ} \mathrm{C}-17^{\circ} \mathrm{C}$ and $17^{\circ} \mathrm{C}-11^{\circ} \mathrm{C}$. Supposedly, the tropics such as Indonesia, the difference in air temperature is based on elevation with detail as follows: lowland 0-300 meter temperature between $33^{\circ} \mathrm{C}-27^{\circ} \mathrm{C}$; at an altitude of $300-900$ meters temperature of $27^{\circ} \mathrm{C}-21^{\circ} \mathrm{C}$; altitude of $1800-2700$ meters $15^{\circ} \mathrm{C}$ temperature $-9^{\circ} \mathrm{C} ; 2700$ to 3600 meters altitude $9^{\circ} \mathrm{C}-3^{\circ} \mathrm{C}$ temperature; altitude of $3600-4500$ meters $3^{\circ} \mathrm{C}-3^{\circ} \mathrm{C}$ temperature; and $4500-5400$ meters $-3^{\circ} \mathrm{C}-9^{\circ} \mathrm{C}$ temperature (Gritzner, 1989; in Usman, 1997).

Form of error associated with the "concept" on a geography textbook Senior High School was found as shown in the following example: "Coal is the youngest of peat. Older than peat is lignite, and coal. Then graphite as a material for pencil. The oldest is a diamond". As we know that young or old age chronology of coal as it does not have the theoretical basis and impressed personal opinion. The concept of peat and diamonds are wrong, because peat and diamonds are not part of the coal. Thus, it is understood that coal is the youngest and the oldest peat is a diamond, it is a form of conceptual errors.

Shape errors of "generalization" in geography textbooks Senior High School was found as seen in the following example: with such an ideal temperature, as described above, the Indonesian population can carry out activities in a longer time each year. Unlike the one in the desert or in the desert of ice. This conclusion is not right, the temperature does not exactly make people work longer, because of the short length of time for a job depends on the type of work. Farming for instance, at a certain time after planting farmers are often unemployed, except for having a second job. In addition, comparison of temperature in Indonesia with in the desert and the ice field completely irrelevant, because the comparison is too extreme. Ultimately difficult to understand by the students.

Misapplication "language" in geography textbooks Senior High School among others are found as in the following example: "Nickel is used as a mixture of iron to improve the quality of the iron itself, or making steel. Used as a metal coating is so shiny and rust resistant". The phrase "Used as a metal coating is so shiny and rust resistant" indicates a form of language errors, because it does not have a subject. In geography textbooks Senior High School is often found paragraphs comprising one short sentence. In the case, should one paragraph contains an idea that consists of a few sentences.

Various errors are found in the presence of geography textbooks in Malang shows that textbooks are less worthy to wear the teachers. That's because, a good textbook will give good influence learning outcomes, and vice versa, the less good textbook will give pangaruh bad for student learning outcomes. As noted Gibson (1980) that the content of the material and content of the text in a book organized poorly, if used for an learning, faster missing compared to when the content material is well organized. Empirical evidence suggests that the organization of teaching materials are carried out according to the elaboration of the model can enhance significant learning gains (Degeng, 1988).

In a matter of learning geography at the Senior High School, malakukan observation of drawings, photographs, models, maps, and the like are done in the classroom (indoor study) is of interest to students. However, the observation field (outdoor study) can make an impact on the activity and creativity of the students in learning. That's because the students do direct observation of the event or events that actually occurred in the field (Fatchan $\&$ Purwanto, 2008). This is in line with the characteristics of the subject matter of Geography that is much related with concrete concepts and facts within the everyday life of students. Outdoor learning through the study is one of the implementation of the scientific model of learning that takes into account local keraifan. The involvement of local wisdom to make the acquisition of a positive learning who can understand the social values of the local culture that exist in the life of the individual concerned (Fatchan, Soekamto, \& Mustafa, 2015). Imlementasi such learning takes a sequence of phases of activity. Stage of the learning activities as follows: (1) observe; (2) classify; (3) communicate; (4) measures; (5) projects; and (6) concluded; and (7) write a report on the results of studies (Bruner, 1978; Gage \& Berliner, 1985).

Outdoor learning Geography study on some of the topics will be the motivation and involvement of the student in understanding abstract concepts, concrete concepts and facts through the learning experience obtained directly in the field. Thus, learning can improve learning outcomes that can be measured concretely and precisely. Such measurements, as also confirmed by Chen (2014) to measure the status of the development of the quality of education in primary and secondary schools in China that the valuation model has good diagnostic functions which according to the actual function. It was, as students learn directly related to the environmental context about the lives of students (Nurhadi, 2002; Rostana, 2002). Learning occurs when changes in student behavior can be observed directly by the teacher. Thus, the learning patterns such teachers act as mentors, facilitators, motivators, and at the same time evaluator directly. In learning the teacher invites students to perform outdoor study, giving the 
freedom of students to develop cognitive, affective, and psychomotor in him (Yager \& Huang, 1994; Woods, 1996; Rostana, 2002).

Based on the above description, it would require an analysis of the various geography text books used by teachers in Senior High School. Analysis directed at a variety of institutional shortcomings and the contents of the textbook. Based on the weaknesses will be exploited as an improvement in the geography text book Malang region in particular and Indonesia in general. It is very necessary because a good organizing textbook allows students to understand the subject matter (Beck \& McKeown, 1988). Furthermore, the content of the material in the standard text book makes easy to understand and "right" in the acquisition of knowledge that is understood by the students. Textbooks good, if in reading the book provides the opportunity for students to observe, ask, try, reason, and communicate as recommended by the Indonesian National Curriculum in 2013 (National Education Standards Agency of the Republic of Indonesia, 2014). Therefore, the purpose of this research is to survey the various Geography textbooks used by teachers in the Senior High School in Malang. The goal is to identify the weaknesses or faults organization and content of the textbook.

\section{Methods}

This study used survey method. Survey conducted on a variety of classes XI Geography textbooks used by teachers in Senior High School and equal in Malang, East Java. The goal is to identify the weaknesses or errors organizing and contents of Geography textbooks used by teachers in Senior High School. To measure the quality of the organization of the textbook use indicators recommended by Beck and McKeown (1988), namely: (1) aside that overwhelm the purpose, (2) inagequate examples and comparisons, (3) poorly odered components of an explanation and, (4) Inadequate explanation. While standards for measuring the quality and content of textbooks using the indicators issued by the National Education Standards Agency of Indonesia (2014), namely: (1) the effective functioning of the media, (2) exposure of the facts, concepts, generalizations, and (3) language. The survey was conducted in Malang include Malang, Batu and Malang East Java Province. The number of schools who responded determined in proportion of $15 \%$ of existing schools. Accordingly, the number of respondents as follows: a total of 18 schools Malang, Batu number 7 school, and Malang some 10 schools. Each respondent was taken by 2 pieces of text books which became the main grip teacher. Thus, each study site found the number of respondents as follows: (1) Malang number of $18 \times 2=36$ samples, (2) Batu number 7 × $2=14$ samples, and (3) Malang number of $10 \times 2-20$ samples. Data were analyzed using percentage table and further explanation is given in the form of a meaningful narrative.

\section{Research Result}

\subsection{Research Related Organizing Geography Textbook}

The results show that the error organizers Geography Class XI textbook in Senior High School, shows the following.

Table 1. Percentage error organizing textbooks

\begin{tabular}{lclll}
\hline No. Aspects Errors /Location & Malang Regency & Batu City & Malang City & Average (\%) \\
\hline 1. Aside that overwhelm the purpose & 37.50 & 28.57 & 20.00 & 28.69 \\
2. Inagequate examples and comparisons & 31.25 & 35.71 & 25.00 & 30.65 \\
3. Poorly odered components of an explanation & 25.00 & 28.57 & 15.00 & 22.85 \\
4. Inadequate explanation & 15.63 & 21.43 & 15.00 & 17.35 \\
Average Errors & 27.34 & 28.57 & 18.75 & 24.89 \\
\hline
\end{tabular}

Based on data in Table 1 above shows that the biggest mistake organizations Class XI textbook Senior High School is on the aspect of "inagequate examples and comparisons". The error indicates a figure of $30.65 \%$. Overall the average error of the textbook shows by $24.89 \%$. Furthermore, attractive smallest error is found in the city of Malang, which amounted to $18.75 \%$.

Errors aspect "inagequate examples and comparisons" showed the greatest percentage, it is shown by the fact that the Class XI textbook does not show photos or images that may dikomparasikan. However, tend to show data, images, or photos are monotonous and ignores the principle of interrelation, descriptive, distribution, and korologi that should appear in the eleventh grade geography textbook. Examples of errors it looked as follows. First, the 
principle of interrelation is a principle that emphasizes the causal relationship in any event geosphere. Interrelation principle aims express the relationship of physical antarfaktor geographic, human antarfaktor, and between physical factors of geography with the human factor. Through such an interrelation relationship, students are expected to be able to reveal the characteristic symptoms or geography facts in a particular place or region. In the eleventh grade Geography text book is exemplified that the floods that occurred in the Solo River Basin due to interruption of balance of natural and human factors. Factors that could cause flash floods caused by illegal logging, heavy rainfall, slope, and arrangement of space that is not appropriate. Errors encountered is that in the Bengawan Solo Watershed illegal logging is not possible, because in this area there are no forests and no incident of illegal logging.

Second, the descriptive principle is the principle of Geography study aimed to provide a more detailed picture of the phenomenon being studied. This principle can be implemented not only through words or maps. However, it should be done through understanding or study of charts, graphs, and tables. Forms of description can give an explanation and clarity about what is being learned or are being investigated. Errors that were found are: flooding in the Bengawan Solo Watershed in East Java which has a number of casualties death, injury, loss of property and loss of items. In the analyzed text book is not presented photos or table on flooding and damages caused by the floods in the Bengawan Solo Watershed in East Java.

Thirdly, the principle of distribution is the symptoms and facts pertaining the geography of human life to the existence of natural resources that are scattered on the earth's surface. Distribution is uneven from one region to another. By observing the various spread of symptoms and the facts of geography on the map or in the real world students will be able to uncover the relationship between each other. Errors were encountered that in the textbooks analyzed not presented pictures, maps pesebaran position volcanoes and volcanic activity data that exists in Indonesia. However, only provides an explanation of positive effects and negative effects of volcanic eruptions.

Fourth, korologi principle is the principle of a comprehensive study. This principle is important for geography materials Senior High School. On the principle of korologi symptoms, facts, and issues from the perspective of geography spread, interrelation and interaction in space. Factors cause and effect of the occurrence of a symptom and the problem always occurs and can not be removed from time and space. Space and time provide the characteristic symptoms of unity, the unity of functions and unity of form. Errors were found in the analyzed text book is not presented map, when explaining about the flood. In the book is not displayed map tografi, location of the height, geomorphological conditions, rainfall, land use patterns, cultural, and slope.

\subsection{Research Related to the Content Standard Textbook Geography}

The analysis showed that the standard error of the content of textbooks Geography Class XI at the Senior High School, shows the following.

Table 2. Percentage error content standards textbooks

\begin{tabular}{lllll}
\hline No. Aspec of Errors/Location & Malang Regency & Batu City & Malang City & Average (\%) \\
\hline 1. Exposure concept & 53.10 & 56.50 & 55.00 & 54.80 \\
2. Exposure fact & 56.10 & 56.50 & 55.00 & 57.10 \\
3. Exposure generalization & 25.00 & 35.70 & 25.00 & 28.60 \\
4. The use of language & 22.80 & 21.40 & 20.00 & 21.40 \\
5. Effective functioning of the media & 61.40 & 57.10 & 60.00 & 59.50 \\
Average Errors & 43.70 & 45.40 & 43.00 & 44.30 \\
\hline
\end{tabular}

Based on the findings of the data content as the standard error in Table 2 above shows that the biggest mistake the contents of Class XI textbook Senior High School is on the aspect of "exposure to the fact". The error indicates a figure of $57.10 \%$. However, encountered some excess in the level of "organizing" the contents of the textbook. Excess exposure indicated that among other "facts" are often associated with local knowledge in the context of student life. Thus, students tend to be easier to make a generalization when reading the text.

When viewed as a whole, the average error shows the contents of the textbook of $44.30 \%$. However, the smallest error encountered on aspects of language use which is equal to $21: 40 \%$ and amounted to $28.60 \%$ of generalization 
error. Furthermore, in some detail the spread of errors concepts, facts, generalizations, language and media functions on any teaching materials can be seen in Table 3 below.

Table 3. Frequency errors concept, fact, generalizations, language, and media in the geography text books of Senior High School

\begin{tabular}{|c|c|c|c|c|c|c|}
\hline \multirow[t]{2}{*}{ No. Materials } & \multicolumn{3}{|c|}{ Total } & \multicolumn{3}{|c|}{ Frequancy Error } \\
\hline & Copetence & Concept & Fact & Generalization & Lenguage & Media \\
\hline 1.Basic Knowledge of Geography & & & & & & \\
\hline $\begin{array}{l}\text { 2.Study geography in studying the } \\
\text { phenomenon of Geosphere }\end{array}$ & 7 & 3 & 4 & 2 & 1 & 5 \\
\hline $\begin{array}{l}\text { 3.The relationship of man and the } \\
\text { environment as a result of the dynamics of } \\
\text { the lithosphere }\end{array}$ & 6 & 6 & 6 & 3 & 1 & 2 \\
\hline $\begin{array}{l}\text { 4.Understanding the dynamics of planet } \\
\text { Earth and the solar system }\end{array}$ & 5 & 1 & 4 & 0 & 1 & 1 \\
\hline $\begin{array}{l}\text { 5.The relationship of man and the } \\
\text { environment as a result of the dynamics of } \\
\text { the lithosphere }\end{array}$ & 6 & 6 & 4 & 4 & 4 & 6 \\
\hline $\begin{array}{l}\text { 6.The relationship of man and the } \\
\text { environment as a result of atmospheric } \\
\text { dynamics }\end{array}$ & 6 & 4 & 1 & 0 & 1 & 3 \\
\hline $\begin{array}{l}\text { 7.The relationship of man and the } \\
\text { environment as a result of the dynamics of } \\
\text { the hydrosphere }\end{array}$ & 7 & 2 & 2 & 3 & 1 & 4 \\
\hline $\begin{array}{l}\text { 8. Mitigation and adaptation to natural } \\
\text { disasters }\end{array}$ & 5 & 1 & 3 & 0 & 0 & 4 \\
\hline Total & 42 & 23 & 24 & 12 & 9 & 25 \\
\hline The percentage of errors & & 54.80 & 57.10 & 28.60 & 21.40 & 59.50 \\
\hline
\end{tabular}

Based on data from Table 3 that most errors contained on the media function by $59.50 \%$. Subsequently, followed by errors of fact by $57.10 \%$ and by $54.80 \%$ misconceptions. While the language errors and generalization is relatively low, amounting to $28.60 \%$ and $21.40 \%$. The conditions reflect that in perngorganisasi Senior High School Geography text book still contained many errors about the function of the media, facts, concepts, language, and generalization. On that basis, then a geography teacher in using text books should need to assess in advance in advance, before the text books is delivered to students.

The size of the assessment is based on the standard text book issued by the National Education Standards. Results of the study of geography text books in Senior High School Malang East Java showed: First, Components of feasibility of contents are: (1) Description of conformity with respect to the competence of the parent and basic competence. Data value indicates that the average 8.50 suitability of the material with The Competence of the Parent and Basic Competence is appropriate. That is the subject matter of Geography in Senior High School most of the contents of the book already contained in the text; (2) The accuracy of material, accuracy value of 7.00 indicates that overall accuracy is good. However, the truth of the components and concepts presented ketepan still need to be addressed; (3) Currentnest, value of 6.33 based on the results of the category of textbooks is quite good. Nevertheless, there is still need improvement on recency examples and references; (4) Growing spiritual attitude, value of 4.00 that means the values of spiritual attitudes in textbooks Geography exsplisit not appear; (5) Growing social attitude, value of 4.00 that means the task is still not applicable to the living environment of students. That is not entered a local wisdom in the lives of students; (6) Developing skills, value of 5.00 that means geography skills still not been applied cognitive ability, so it needs to be developed a task/material constructive "geography skills"; (7) Knowledge to develop insight, value of 5.00 that means assessment study of aspects of spiritual attitudes, social skills, and the development of insight knowledge is still lacking.

Second, aspect of presentation as showed: (1) Presentation techniques, component presentation technique is good because the score had reached 7.25. However, in this component still needs to be improved; (2) Presentation of supporting materials, component presentation of the material supporting the average value of 8.14. It means indicates that the component is in the category has been good; (3) Presentation of learning, the presentation aspect 
of learning got an average score of 6.16. This means that despite being in either category, but still need for improvement.

Based on these results indicate that the weakness of the text books in the National Curriculum Geography Indonesia lies in the following components: (1) growing spiritual attitude, (2) foster social attitudes, and (3) foster "geography skills". Where each of these components has a score of 5 to the bottom. This means that by the National Education Standards on these components are still in the category of "less". While the remaining components on average $\geq 6$ is considered "good". However, the components that have been well does not mean there have errors. If viewed in detail on these components still have errors. Ere is what can be improved by using pengorgnisasi text books.

\section{Discussion}

The results showed that in textbooks on geography Senior High School encountered a lot of mistakes. Most errors occur in the function of the media. Media function in the textbooks are not effective and do not support the description of the material. Form errors were found: (1) there is no media to support the explanation of the material, (2) the media is there but do not function effectively, and (3) the placement of media that is not right. In the case, the function of the media are a very important role in the implementation of the national curriculum in 2015. Mainly to build students' skills in understanding the material geography. The findings reinforce the results of research on teaching and learning of the new curriculum in Tanzania High School. The findings reveal that poor competency-based curriculum is implemented by teachers in Tanzania. That, indicated the majority of teachers do not understand the requirements of the new curriculum implementation (Komba \& Mwandanji, 2015). The research findings also indicate that exposure error "fact" is very large, i.e., $57.1 \%$. The fault shape in the form of exposure to theory presented in textbooks is not supported by the facts. In the case should have presented the facts of geography that supports the theory. The fact that it must diaparka such as data, graphs, tables, maps, photographs, charts, models and the like.

Exposure error "concept" in a geography text book shows very large: $54.8 \%$. Examples of error was as follows: "The mountain is a mountain break at any time erupt and then break back. For example, Mount Ciremai and Kelud in East Java". On exposure to the concept shows not suitable to clarify the facts. Because the actual fact that Kelud is an active volcano. It can be seen that the fact Kelud often erupts. Until now Kelud continue to emit sulfur fumes from the crater. This error can result in the Geography textbooks Senior High School is not easily understood by students.

Based on these findings it can be said that the textbook Geography at Senior High School in the research area of less help students to learn geography. It can even be misleading knowledge of geography students. The research findings conflict with the demands of the National Curriculum of the Republic of Indonesia in 2013. Where in the curriculum is demanding incorporate local wisdom values of socio-cultural "culturally diverse". Context of such useful local knowledge for the students to understand the facts of life and the life of the various values. As noted by the research findings tedahulu Cotton (1991) and Fatchan et al. (2004).

The fact has very limited value against time, places, and events. While the concepts and generalizations have a wider transfer of value in helping people to discover new knowledge. The research findings show that the error "generalization" in a geography textbook in class XI is low. In other words, using such textbooks are basically students have a pretty good chance to find a "generalization". The finding new knowledge derived from the ability to create a "generalization" in a "bottom up" resulted in "longterm memory" stronger students. It happened because in textbooks (which are analyzed in this study) description often associated with the context of local knowledge around student life environment. This reinforces the findings of previous research in Zimbabwe that the high rate of employment of teachers applying the integrated curriculum seems to be a motivator. Curriculum and education is more beneficial for sustainable entrepreneurship development when learning is done in line with the context of student life (Dambudzo, 2015). However, the uniqueness of the findings of this research is in the context of local knowledge about the environment of student life as material for building concepts and generalizations in a matter of geography. That's the newness of this research.

Previous research findings explain that the role of learning in geography Senior High Schoool in Indonesia is still dominated by facts and concepts. While learning towards "finding" generalization is still very small (Purwanto, 1998; Purwanto, Sumarmi, \& Amirudin, 2000). Conditions in the Geography textbooks Senior High Schoool such a result of student learning activities tend to memorize facts and concepts. Consequently occurring students proficient cognition but only weakly in attracting a concept and generalization. Gagne and Briggs call as students tend to understand the meaning of concepts and generalizations, but never use a rule to solve the problem (Gagne $\&$ Briggs, 1979). The research findings seem to support the notion that Gagne and Briggs. 
In the IPS-Geography lessons in junior high schools, students are not required to learn all the facts about the place. But how do students get the information needed when studying a topic (Skeell, 1995). Therefore, that is widely used in the learning of IPS-Geography is maps, globes, and data to study somewhere. It is different when the material studied Geography at Senior High School. Senior in High School students are required to solve the phenomenon of the geosphere. In order to solve the phenomenon of the geosphere, the material presented in the textbook should be equipped with data. Exposure data in eleventh grade geography text book shows is still lacking. This means that the contents of textbooks are not yet fully encourage the students to study well (BSNP, 2014). In addition, a less obvious form of the command is also not equipped with data and facts. Likewise organizing the contents of geography textbooks in class XI shows many common weaknesses. In the case, the presentation of the contents of textbooks are organized has an important contribution to the quality of understanding (Beck \& McKeown, 1988). Likewise factors and organizational structure of the reading material is an important factor in the ease of understanding the text book (Alexander et al., 1988). Various advantages of textbooks presented by the experts have not been found in geography textbooks studied in this research. It was a weakness and shortcomings which became the research findings, which need further study to improve it.

Observation of the facts in the form of drawings, photographs, data, and maps of the event that there is a very meaningful to student learning gains on the materials Geography. Utilization of the surrounding environment is very necessary for a learning process. It can enhance the creativity and student learning outcomes (Gage \& Berliner, 1985; Kunkel, 1975). This is reinforced by the findings, Fatchan et al. (2004) and Fatchan, Amirudin, and Utaya (2012) that the learning approach is based on the context of the environmental condition of student learning outcomes tend to be better. Observation of the student to the drawings, photographs, data, maps, and the like will be able to improve students' reasoning skills. Reasoning skills to make students be able to answer questions that require reasoning in solving scientific problems. This makes students understand the material provided and associate with problems in their environment, so that the learning outcomes they get into high (Amirudin, Fatchan, \& Sumarmi, 2009). Lawson (1992) proved that the reasoning skills is the most consistent predictor of the learning outcomes than other variables such as style, cognitive, mental capacity, and fluid Intelligence. Learning to use a textbook with pictures, photographs, data, maps, and the like that are still lacking in the textbook geography into this research study. Nevertheless, described in the description contents of the textbook has the advantage that a lot of leads on the context of local knowledge around student life.

\section{Conclusion}

Errors were found in the textbook Geography class XI used by teachers in Senior High School include: First, the error in the organization of the textbook includes: (1) aside that overwhelm the purpose, (2) inagequate examples and comparisons, (3) poorly odered components of an explanation and, (4) Inadequate explanation. Second, the standard error of the contents include (1) the effective functioning of the media, (2) exposure of the facts, (3) exposure draft, (4) the exposure of generalization, and (5) language. Media functions less well in geography text book content resulted in the implementation of the national curriculum in 2015 is also not good. This is in line with the findings of research in Tanzania. Textbooks analyzed in this research that the description associated with the context of strengthening the local knowledge of students in the "find" generalization. Such findings complement the research in Zimbabwe that the continuity of entrepreneurship awake when learning is in line with the context of student life. Context of local wisdom that is presented in the form of drawings, photographs, data, and maps on some of the material in the text book which became the object of geography is very meaningful for the students' learning gains. These findings support several previous research such as Kunkel; Gage and Berliner; Lawson; Fatchan et al; Fatchan, Amirudin, and Utaya who noted that learning is based on the context of the environmental conditions and media images, photographs, data, maps, and the like results in student learning outcomes tend to be.

\section{References}

Alexander, J. E. et al. (1988). Teaching Reading. Chicago: Scott, Foresman and Co.

Amirudin, A., Fatchan, A., \& Sumarmi. (2009). The Outdoor Learning Study to Increase Activity and Results Students Learn Some Vital Lessons in the Area of Natural Disaster Prone. Jakarta. Director General of Higher Education, The Republic of Indonesia.

Beck, I. L., \& McKeown, M. G. (1988). Toward Meaningful Accounts in History Texk for Book. Chicago: Scott, Foresman and Co.

Chen, B. (2014). Constructing Assessment Model of Primary and Secondary Educational Quality with Talent Quality as the Core Standard. Canada. Journal of Education and Learning, 3(4), 108-116. http://dx.doi.org/10.5539/jel.v3n4p108 
Cotton, K. (1991). School-Community Collaboration to Improve the Quality of Life for Urban Youth and Their Families. School Improvement Research Series, 1-28.

Dambudzo, I. I. (2015). Issues Curriculum: Teaching and Learning for Sustainable Development in Developing Countries: Zimbabwe Case Study. Canadian. Journal of Education and Learning, 4(1), 11-24. http://dx.doi.org/10.5539/jel.v4n1p11

Degeng, I. N. S. (1988). Organizing Teaching Based Elaboration Theory and Its Effect on Acquisition of Verbal Learning and Concept Information (Dissertation). Malang: PPS Malang Teachers' Training College.

Fatchan, A. et al. (2004). Evaluation of Basic Education Transformation in East Lombok. Universitas Negeri Malang-Plan International Indonesia, Malang, Surabaya.

Fatchan, A., \& Edy, P. (2008). Contextual Learning for SMP in Disaster Prone Regions in East Java. Jakarta, Director General of Higher Education, The Republic of Indonesia.

Fatchan, A., Amirudin, A., \& Utaya, S. (2012). Effect of Learning Task Group Based on Field Survey (Outdoor Study) for Scientific Writing Ability and Student Results. Journal of Education, 18-35.

Fatchan, A., Hadi, S., \& Mustofa. (2015). Defections “Kiai”, “Ustadz” and Farmers In The New Order and The Reform Order In The Islamic Tradition In Rural East Java. Journal of Culture, Society and Development, 7.

Gagne, N. L., \& Berliner, D. C. (1985). Educational Psycology. USA, New York, Gulf Publishing.

Gagne, R. M., \& Briggs, L. J. (1979). Priciples and Instructional Design. New York, Holt, Rinehard and Wiston.

Gibson, J. T. (1980). Psychology for the Classroom (2nd ed.). Englewood Cliffs: Prentise-hall, Inc.

Komba, S. C., \& Mwandanji, M. (2015). Reflections on the Implementation of Competence Based Curriculum in Tanzanian Secondary Schools. Canada. Journal of Education and Learning, 4(2). http://dx.doi.org/10.5539/jel.v4n2p73

National Education Standards The Republic of Indonesia. (2014). Assessment Instrument of Book. Jakarta, Education Directorate of Senior High School, Indonesia Ministey of Education.

Purwanto, E. (1998). Effect of Text Field Studies Geography Organizing Model Beck and McKeown, Literacy, and Learning Styles to the Acquisition of Learning Reading Student Junior. Graduate Program. Malang State University.

Purwanto, E., \& Sumarmi, A. A. (2000). Validation Subjects Geography Junior Based Social Studies 1994 Curriculum in Malang. Malang, Malang Teachers' Training Institute of Research.

Rostana, E. C. (2002). Learning Contextual Teaching. Jakarta: Ministry of National Education Directorate General of Primary and Secondary Education Directorate Junior High School.

Skeell, D. J. (1995). Elementary Social Studies Challenges for Tomorrow's World. New York: Harcourt Brace And Company.

Tempo. (2000). Procurement Scandal School Book Project: The Industrious Fool Base. Tempo.

Usman, C. H. (1997). Geography Class One for Junior Midle School. Bandung. CV. Djatnika.

Van Cleaf. (1991). Action in Elementary Social Studies. Boston: Allyn and Bacon.

Woods, D. R. (1996). Teaching and Learning: What can Research Tell USA. Journal of College Science Teaching, $X X V(3), 229-232$.

Yager, R. E., \& Huang, D. (1994). An Alternative Approach to College Science Education for nonscience Majors. Journal of College Science Teaching, 98-100.

Zevin, J. (1992). Social Studies for the Twenty-fist Century. New York: Longman.

\section{Copyrights}

Copyright for this article is retained by the author(s), with first publication rights granted to the journal.

This is an open-access article distributed under the terms and conditions of the Creative Commons Attribution license (http://creativecommons.org/licenses/by/3.0/). 